\title{
Hurlstone Park
}

\section{Lesley Muir and Brian Madden}

Hurlstone Park, in the City of Canterbury, is part of the traditional land of the Wangal people. Hawkesbury sandstone outcrops form cliffs above Cooks River at the southern edge of the suburb, and two small creeks once ran down the hill from the Canterbury Road ridge, ending in wetlands along the river bank.

The land was part of a 673-acre (272.3-hectare) estate, inherited by Sophia Ives Campbell in 1846 from her father, the Sydney merchant Robert Campbell. Sophia subdivided her estate in 1865 into farm blocks fronting three roads, which were probably the old cart tracks used by quarrymen to access the quarries that produced sandstone used to build the Sugarworks (1840-42) and St Paul's Church (1859-60) at Canterbury. These roads were later named Floss Street, Kilbride/Burnett Street and Fernhill Street (now Foord Avenue). The rich clay deposits beside the creeks provided raw material for brickmakers Anthony and Richard Blamire and William and Elijah Pendlebury towards the end of the nineteenth century.

In 1874, Sophia Campbell resubdivided her estate into smaller farms, naming Canberra Street after the locality of Duntroon, the Campbell family’s estate in today's Australian Capital Territory. Dunstaffenage, Duntroon, Kilbride, Melford and Crinan Streets commemorate landmarks in Scotland associated with the family's ancestors. Dairy farmers, brickmakers and land speculators bought some of the allotments, but many remained unsold until after the route of the branch railway from Marrickville to Belmore, passing through this land, was approved. When the new railway opened in 1895, a railway station called Fernhill was located at the junction of Duntroon, Crinan and Floss Street. It was named after Sophia Campbell's home near Bournemouth in Hampshire (England), where she died in 1891. Some development occurred near the railway station at the time the line was opened, but the real building boom took place at the height of the Federation period, between the turn of the century and the end of World War I, when the small farms were subdivided into housing estates, and builders from Fernhill, Croydon, Ashfield and Marrickville were active all over the suburb. Many of these new subdivisions were made by Sophia Campbell's nephew John Jeffreys of Canterton (England), and her great-nephew George Darell Jeffreys, who inherited her estate.

In 1910, a new post office was approved for Fernhill, but the Postal Department insisted that the name of the locality would need to be changed as there were already two post offices with that name, one in Victoria and one in Queensland. A local referendum was held in conjunction with a municipal election, the choice being between Hurlstone, Fernboro or Garnett Hill. Hurlstone was selected. This was the name of a college that had been founded by John Kinloch (on the site of 
today's Yeo Park, South Ashfield) and given his mother’s maiden name. Kinloch also owned land near Fernhill railway station. The original Hurlstone College buildings, designed by John Horbury Hunt in 1878, are now part of Trinity Grammar School. The Department of Railways agreed to the change provided that 'Park' was added to avoid confusion with Hillston in western New South Wales.

The tramline from Petersham to Dulwich Hill was extended along New Canterbury Road in 1913, to a terminus at the junction of Old and New Canterbury Roads, a locality formerly known as Wattle Hill. Later, tramlines from Summer Hill, Balmain, and an extension to Canterbury also served the area. This improvement in public transport encouraged development of shops around the terminus, so Hurlstone Park had two shopping strips for much of the twentieth century, one near the railway station, and one on New Canterbury Road.

Many of the builders and their apprentices who built the suburb are commemorated on the Hurlstone Park War Memorial, which was originally erected at the railway station in 1920, and was moved to Euston Reserve after World War II.

In the second half of the twentieth century, the suburb's population changed gradually as homes built around World War I were sold when their original owners retired or died. Many of these houses were bought by postwar immigrants from southern Europe. The population shift was reflected in the change in appearance of many of the houses, and also in the change of use of existing buildings: for instance, St Stephen’s Anglican Church on New Canterbury Road was sold and became St Stephanos Greek Orthodox Church.

Federation era houses of Hurlstone Park which remain in original condition have become very popular with young couples seeking a heritage property to restore, and the composition of the population is changing yet again in the early twenty-first century.

Lesley Muir and Brian Madden are Sydney historians

\section{References}

David R Keenan, The South-Western Lines of the Sydney Tramway System, Transit Press, Petersham, 1992

Ken Kershaw, Arthur Jeffreys and Family in Australia, the author, Sydney, 2008

Frederick A Larcombe, Change and Challenge: a History of the Municipality of Canterbury, NSW, Canterbury Municipal Council, Canterbury, 1979

Brian Madden and Lesley Muir, Canterbury Farm 200 Years, Canterbury and District Historical Society, Earlwood, 1993 
Lesley Muir, (ed), Canterbury’s Boys: World War I and Sydney’s Suburban Fringe, Canterbury and District Historical Society, Kingsgrove, 2002

Lesley Muir, The Bankstown Line: Sydenham to Belmore 1895, Canterbury and District Historical Society, Kingsgrove, 1995

Lesley Muir, 'The Story of the Hurlstone Estate’, Canterbury and District Historical Society Journal, series 2 no 10, 1978

Subdivision Plans, Canterbury and Hurlstone Park, Mitchell Library, Sydney 